\title{
Methanolic Extract of the Herb Ononis spinosa L. Is an Antifungal Agent with No Cytotoxicity to Primary Human Cells
}

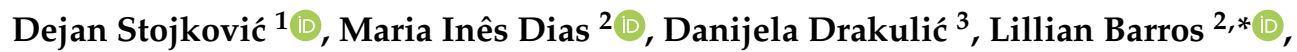 \\ Milena Stevanović ${ }^{3,4,5}$, Isabel C. F. R. Ferreira ${ }^{2}$ (D) and Marina D. Soković $1, *(\mathbb{D})$ \\ 1 Department of Plant Physiology, Institute for Biological Research "Siniša Stanković"- National Institute of \\ Republic of Serbia, University of Belgrade, Bulevar despota Stefana 142, 11000 Belgrade, Serbia; \\ dejanbio@ibiss.bg.ac.rs \\ 2 Centro de Investigação de Montanha (CIMO), Instituto Politécnico de Bragança, Campus de Santa Apolónia, \\ 5300-253 Bragança, Portugal; maria.ines@ipb.pt (M.I.D.); iferreira@ipb.pt (I.C.F.R.F.) \\ 3 Institute of Molecular Genetics and Genetic Engineering, University of Belgrade, Vojvode Stepe 444a, \\ 11042 Belgrade, Serbia; danijeladrakulic@imgge.bg.ac.rs (D.D.); milenastevanovic@imgge.bg.ac.rs (M.S.) \\ 4 Faculty of Biology, University of Belgrade, Studentski trg 16, 11000 Belgrade, Serbia \\ 5 Serbian Academy of Sciences and Arts, Knez Mihailova 35, 11001 Belgrade, Serbia \\ * Correspondence: lillian@ipb.pt (L.B.); mris@ibiss.bg.ac.rs (M.D.S.); Tel.: +351 27318303219 (L.B.); \\ +381-11-207-84-19 (M.D.S.); Fax: +351 273325405 (L.B.); +381-11-2-761-433 (M.D.S.)
}

Received: 10 March 2020; Accepted: 23 April 2020; Published: 24 April 2020

\begin{abstract}
Ononis spinosa L. is a plant traditionally used as folk remedy. There are numerous studies regarding chemical constituents and health beneficial properties of Ononidis Radix. The following study was designed to investigate chemical composition and antifungal potential of the methanolic extract obtained from the O. spinosa L. herb. Chemical analyses regarding phenolic compounds of O. spinosa were performed by liquid chromatography with mass spectrometry (LC-DAD-ESI/MSn). Antifungal activity, antibiofilm properties and antifungal mode of action of the extract were evaluated, as well as cytotoxicity. Chemical analyses revealed the presence of flavonoids, isoflavonoids and phenolic acids in $\mathrm{O}$. spinosa, with kaempherol-O-hexoside-pentoside being the most abundant compound (5.1 mg/g extract). Methanolic extract was active against all of the tested microfungi with Penicillium aurantiogriseum being the most sensitive to the extract inhibitory effect at $0.02 \mathrm{mg} / \mathrm{mL}$; and effectively inhibited biofilms formed by Candida strains. Minimum fungicidal concentrations of extract rose in the presence of ergosterol and leakage of cellular components was detected. The extract showed no cytotoxicity to human gingival fibroblast (HGF-1) cells. This study significantly contributes to overall knowledge about medicinal potential of O. spinosa herbal extract and enlightens previously unrevealed properties. O. spinosa aerial parts seem to be an interesting candidate for the development of antifungal preparations, non-toxic to human cells.
\end{abstract}

Keywords: O. spinosa; methanolic extract; aerial parts; phenolic compounds; antifungal; antibiofilm; cytotoxicity

\section{Introduction}

Colossal structural diversity and biological activity of natural molecules are unrivaled by any available synthetic drugs in reference libraries. As such, these privileged platforms derived from nature serve as important scaffolds for the design of novel therapeutic candidates, including antifungals.

More than a billion people are suffering from various fungal infections, with more than 1.5 million having fatal consequences [1]. These infections are difficult to treat making the mortality rates high 
even in the 21th century, despite various antifungals that are currently available [1]. Even more, fungal biofilms is difficult to treat since they show resistance to the host immune system and conventional antifungal treatment when compared to free floating cells [2].

Ononis spinosa L. (Fabaceae), spiny restharrow an ethomedicinal plant [3], is widespread in almost all of Europe, western Asia and northern Africa [4,5]. European Pharmacopoeia has recorded $O$. spinosa dried roots as "Ononidis Radix". The roots of $O$. spinosa are known to be used as diuretic and anti-inflammatory agent, as well as in a variety of skin conditions, including itches, wounds, burns and dermatitis (eczema) [6-9]. The ashes obtained after burning the plant samples of O. spinosa were previously shown as active against different Candida species [3]. Previous phytochemical investigation of $O$. spinosa revealed the presence of flavonoid derivatives, sterols and terpene compounds [10-12]. Previous antifungal investigations of plants belonging to Ononis genera have shown that extracts obtained from Ononis species have antibacterial and antifungal effects $[13,14]$.

Bearing in mind that most of the investigations of $O$. spinosa as healing plant are focused on the analysis of the phytochemicals and health beneficial properties from the roots, and that ethno-medicinal use of $O$. spinosa aerial parts is limitedly described in the literature, the aim of this study was to identify phenolic compounds presented in aerial parts of $O$. spinosa and to investigate potential antifungal properties of methanolic extract against wide spectrum of fungal pathogens and contaminants. Additionally, effects of the methanolic extract on the biofilm formation by Candida albicans, C. tropicalis and C. krusei have been analyzed. Furthermore, analysis of ergosterol and cytoplasmic membrane as potential targets for the activity of the extract was set as one of the goals of this study, as well as the cytotoxic effect of methanolic extract on primary human gingival fibroblast cells.

\section{Results and Discussion}

\subsection{Chemical Composition of Phenolic Compounds}

The chromatographic data obtained from the High-Performance Liquid Chromatography coupled with a Diode Array Detector and Electrospray Mass Spectrometry (HPLC-DAD-ESI/MSn) analyses of the phenolic compounds in the extracts of $O$. spinosa are presented in the Table 1 and Figure 1 . We have identified 16 compounds in the extract, which are counting seven flavonoids, five phenolic acids and four isoflavonoids. Chromatographic characteristics corresponding to standard compounds caffeic acid, quercetin-3-O-glucoside and kaempherol-3-O-glucoside, were used for positive identification of Peaks 3, 9 and 13, respectively. The most abundant class of the compounds were flavonoids with the highest number of tentatively identified compounds and with the highest quantity $(12.2 \pm 0.1 \mathrm{mg} / \mathrm{g}$ extract) as well. Peaks $7\left([\mathrm{M}-\mathrm{H}]^{-}\right.$at $m / z$ 609), $10\left([\mathrm{M}-\mathrm{H}]^{-}\right.$at $\left.m / z 579\right)$ and $12\left([\mathrm{M}-\mathrm{H}]^{-}\right.$at $m / z$ 447), had given a particular $\mathrm{MS}^{2}$ fragment at $m / z 285$ (kaempherol aglycone), analogous to the loss of $324 \mathrm{u}$ (two hexosyl units), $294 \mathrm{u}$ (one hexosyl and one pentosyl unit) and $162 \mathrm{u}$ (one hexosyl unit), respectively. These Peaks $(7,10$ and 12) were tentatively identified as kaempherol-O-dihexoside, kaempherol-O-hexoside-pentoside and kaempherol-O-hexoside (with a different retention time when compared to the peak 13), respectively. According to their chromatographic characteristics, Peaks 6 and 11 were found to be glycosylated derivatives of quercetin, and these were further identified as quercetin-O-hexoside-pentoside and acetylquercetin-O-hexoside, respectively. As far as the authors knowledge there are no previous reports on $O$. spinosa regarding the identification of this type of flavonoids. Nevertheless, these types of compounds have been previously identified in others Ononis varieties, such as O. arvensis [15] and O. angustissima L. [16] aerial parts. 
Table 1. Retention time (Rt), wavelengths of maximum absorption in the visible region $\left(\lambda_{\max }\right)$, mass spectral data and tentative identification of the phenolic compounds present in Ononis spinosa L.

\begin{tabular}{|c|c|c|c|c|c|c|}
\hline Peak & Rt (min) & $\lambda_{\max ((\mathrm{nm}))}$ & $\begin{array}{c}\text { Molecular Ion } \\
{\left[\mathbf{M}-\mathbf{H}^{-}(m / z)\right.}\end{array}$ & $\operatorname{MS}^{2}(m / z)$ & Tentative Identification & Quantification (mg/g Extract) \\
\hline 1 & 5.31 & 310 & 341 & 179(100),135(5) & Caffeic acid hexoside ${ }^{A}$ & $\operatorname{tr}$ \\
\hline 2 & 6.55 & 287 & 355 & $193(100), 179(5), 149(5)$ & Ferulic acid hexoside ${ }^{B}$ & $0.078 \pm 0.001$ \\
\hline 3 & 9.93 & 310 & 179 & $135(100)$ & Caffeic acid A & $0.020 \pm 0.001$ \\
\hline 4 & 13.66 & 328 & 473 & $311(100), 293(92), 267(5), 179(5), 149(8), 135(5)$ & cis Chicoric acid A & $0.81 \pm 0.02$ \\
\hline 5 & 14.17 & 328 & 473 & $311(100), 293(90), 267(5), 179(5), 149(10), 135(5)$ & trans Chicoric acid A & $0.76 \pm 0.01$ \\
\hline 6 & 15.96 & 348 & 595 & 301(100) & Quercetin-O-hexoside-pentoside ${ }^{C}$ & $0.824 \pm 0.001$ \\
\hline 7 & 16.43 & 341 & 609 & $285(100)$ & Kaempherol-O-dihexoside $\mathrm{C}$ & $0.732 \pm 0.002$ \\
\hline 8 & 17.11 & 305 & 459 & $297(100)$ & Spinonin-O-hexoside $\mathrm{E}$ & $\operatorname{tr}$ \\
\hline 9 & 18.5 & 328 & 463 & $301(100)$ & Quercetin-3-O-glucoside ${ }^{\mathrm{D}}$ & $0.61 \pm 0.01$ \\
\hline 10 & 19.07 & 346 & 579 & $285(100)$ & Kaempherol-O-hexoside-pentoside ${ }^{C}$ & $5.1 \pm 0.2$ \\
\hline 11 & 20.58 & 348 & 505 & $463(70), 301(100)$ & Acetylquercetin-O-hexoside $\mathrm{D}$ & $0.566 \pm 0.002$ \\
\hline 12 & 21.18 & 337 & 447 & $285(100)$ & Kaempherol-O-hexoside ${ }^{\mathrm{D}}$ & $0.58 \pm 0.01$ \\
\hline 13 & 22.37 & 340 & 447 & 285(100) & Kaempherol-3-O-glucoside ${ }^{\mathrm{D}}$ & $0.71 \pm 0.02$ \\
\hline 14 & 25.34 & $262 / 291$ & 489 & 281(100) & Pseudobaptigenin- $O$-hexoside ${ }^{\mathrm{E}}$ & $0.134 \pm 0.003$ \\
\hline 15 & 26.56 & $261 / 310$ & 475 & $267(100)$ & Formononetin derivative $\mathrm{F}$ & $1.28 \pm 0.02$ \\
\hline \multirow[t]{4}{*}{16} & 31.18 & $260 / 310$ & 515 & $471(15), 429(5), 267(100)$ & Formononetin-O-malonyl-hexoside ${ }^{\mathrm{F}}$ & $\operatorname{tr}$ \\
\hline & & & & & Total phenolic acids & $1.66 \pm 0.03$ \\
\hline & & & & & Total flavonoids & $9.1 \pm 0.1$ \\
\hline & & & & & Total phenolic compounds & $12.2 \pm 0.1$ \\
\hline
\end{tabular}




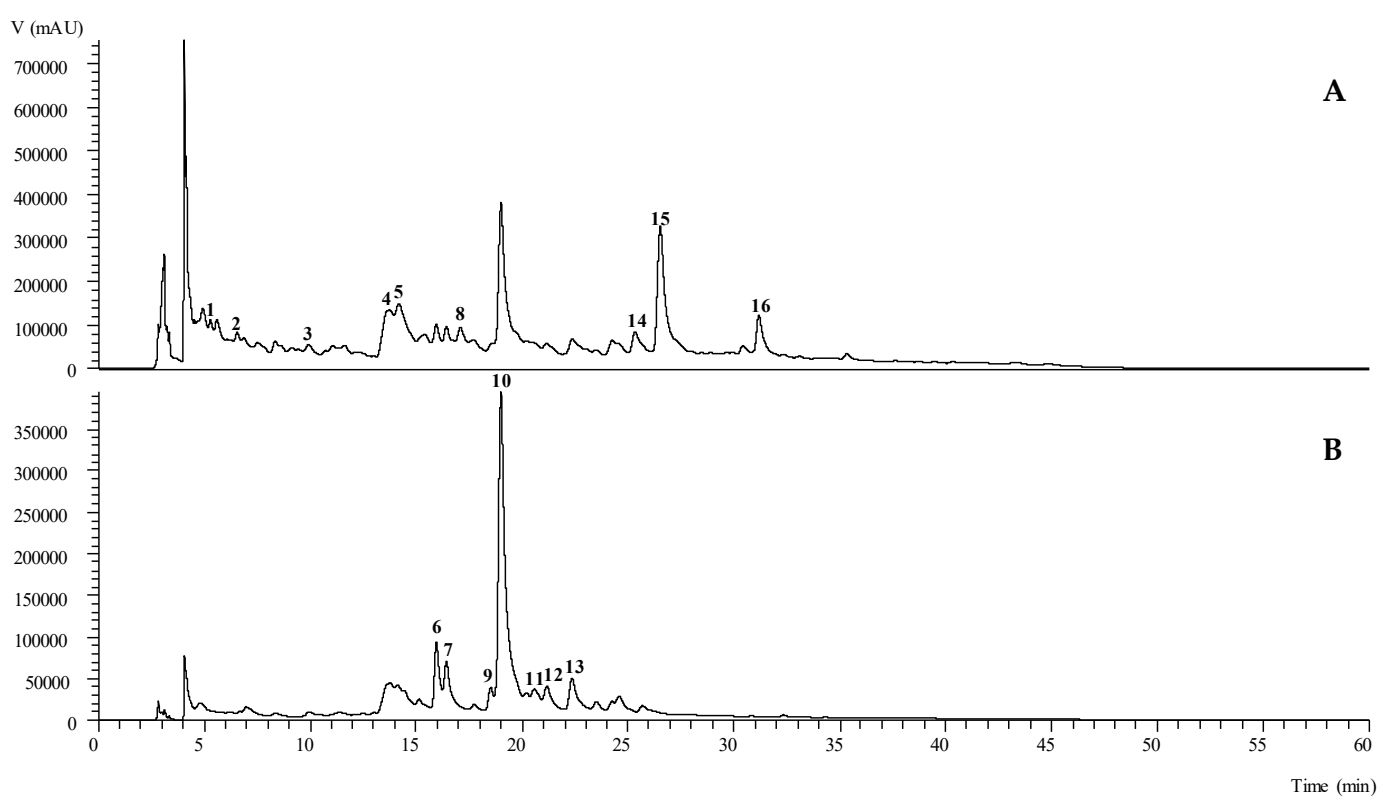

Figure 1. Retention time (Rt), wavelengths of maximum absorption in the visible region $\left(\lambda_{\max }\right)$, mass spectral data and tentative identification of the phenolic compounds present in Ononis spinosa L., recorded at $280 \mathrm{~nm}(\mathbf{A})$ and $370 \mathrm{~nm}(\mathbf{B})$.

Regarding the phenolic acids group, peaks $1\left([\mathrm{M}-\mathrm{H}]^{-}\right.$at $\left.m / z 341\right)$ and $2\left([\mathrm{M}-\mathrm{H}]^{-}\right.$at $m / z$ 355) were tentatively identified as caffeic acid hexoside and ferulic acid hexoside, respectively, based on its characteristic Ultraviolet-Visible (UV-Vis) spectra, fragmentation pattern and the information previously reported by Barros et al., [17]. Peaks 4 and $5\left([\mathrm{M}-\mathrm{H}]^{-}\right.$at $\left.m / z 473\right)$ were tentatively identified as the cis and trans isomers of chicoric acid, respectively, based on the chromatographic information previously reported by Chen et al., [18]. As previously mentioned, to the best of our knowledge there are no studies, on the composition in phenolic acids in O. spinosa. Nevertheless, these types of compounds have already been reported in the O. angustissima L. aerial parts [16].

Finally, the groups of isoflavonoids found in O. spinosa were less abundant in comparison to the other two groups of phenolic compounds. Though, this group has been extensively studied in O. spinosa [19-22]. Peaks 8 ([M - H $]^{-}$at $\left.m / z 459\right), \mathbf{1 4}\left([\mathrm{M}-\mathrm{H}]^{-}\right.$at $\left.m / z 489\right), \mathbf{1 5}\left([\mathrm{M}-\mathrm{H}]^{-}\right.$at $\left.m / z 459\right)$ and $\mathbf{1 6}\left([\mathrm{M}-\mathrm{H}]^{-}\right.$at $m / z$ 515), were tentatively identified as spinonin-O-hexoside, pseudobaptigenin-O-hexoside, formononetin derivative and formononetin-O-malonyl-hexoside, respectively, based on its chromatographic characteristic, as also their fragmentation pattern, which has been previously reported by Gampe et al. [5]. Although two of these compounds were found in trace amounts in the studied sample (peaks 8 and 16), it is important to highlight the relevance of isoflavonoids to human health, having already been intensively studied, mainly in legumes, for their effects to inhibit the proliferation of certain types of cancers or even against some neurodegenerative diseases [23,24].

\subsection{Antifungal Activity of O. spinosa Methanolic Extract}

Antifungal activity of the methanolic extract obtained from the aerial parts of $O$. spinosa is presented in Table 2. The activity of extract was tested against wide range of pathogenic and contaminant fungi, including human, animal and plant pathogens, as well as food contaminant species. 
Table 2. Antifungal activities of O. spinosa methanolic extract (MIC (minimum inhibitory concentration) and MFC (minimum fungicidal concentration) $\mathrm{mg} / \mathrm{mL}$ ).

\begin{tabular}{ccccc}
\hline Microfungi & & O. spinosa & Ketoconazole & Bifonazole \\
\hline A. fumigatus & MIC & $0.08^{\mathrm{b}}$ & $0.20^{\mathrm{a}}$ & $0.15^{\mathrm{b}}$ \\
(ATCC 9197) & MFC & $0.08^{\mathrm{b}}$ & $0.50^{\mathrm{b}}$ & $0.20^{\mathrm{a}}$ \\
A. versicolor & MIC & $0.62^{\mathrm{d}}$ & $0.20^{\mathrm{a}}$ & $0.10^{\mathrm{a}}$ \\
(ATCC 11730) & MFC & $1.25^{\mathrm{d}}$ & $0.50^{\mathrm{b}}$ & $0.20^{\mathrm{a}}$ \\
A. niger & MIC & $0.62^{\mathrm{d}}$ & $0.20^{\mathrm{a}}$ & $0.15^{\mathrm{b}}$ \\
(ATCC 6275) & MFC & $1.25^{\mathrm{d}}$ & $0.50^{\mathrm{b}}$ & $0.20^{\mathrm{a}}$ \\
A. ochraceus & MIC & $2.50^{\mathrm{e}}$ & $1.50^{\mathrm{e}}$ & $0.15^{\mathrm{b}}$ \\
(ATCC 12066) & MFC & $2.50^{\mathrm{e}}$ & $2.00^{\mathrm{e}}$ & $0.20^{\mathrm{a}}$ \\
Trichoderma viride & MIC & $0.62^{\mathrm{d}}$ & $1.00^{\mathrm{d}}$ & $0.15^{\mathrm{b}}$ \\
(IAM 5061) & MFC & $1.25^{\mathrm{d}}$ & $1.00^{\mathrm{c}}$ & $0.20^{\mathrm{a}}$ \\
Penicillium funiculosum & MIC & $0.62^{\mathrm{d}}$ & $0.20^{\mathrm{a}}$ & $0.20^{\mathrm{c}}$ \\
(ATCC 36839) & MFC & $1.25^{\mathrm{d}}$ & $0.50^{\mathrm{b}}$ & $0.25^{\mathrm{b}}$ \\
P. aurantiogriseum & MIC & $0.02^{\mathrm{a}}$ & $0.20^{\mathrm{a}}$ & $0.10^{\mathrm{a}}$ \\
(food isolate) & MFC & $0.04^{\mathrm{a}}$ & $0.30^{\mathrm{a}}$ & $0.20^{\mathrm{a}}$ \\
P. ochrochloron & MIC & $5.00^{\mathrm{f}}$ & $1.00^{\mathrm{d}}$ & $0.20^{\mathrm{c}}$ \\
(ATCC 9122) & MFC & $10.00^{\mathrm{f}}$ & $1.50^{\mathrm{d}}$ & $0.25^{\mathrm{b}}$ \\
Candida albicans & MIC & $0.62^{\mathrm{d}}$ & $0.50^{\mathrm{c}}$ & $0.15^{\mathrm{b}}$ \\
(ATCC 10231) & MFC & $1.25^{\mathrm{d}}$ & $1.00^{\mathrm{c}}$ & $0.30^{\mathrm{c}}$ \\
C. krusei & MIC & $0.62^{\mathrm{d}}$ & $0.50^{\mathrm{c}}$ & $0.25^{\mathrm{d}}$ \\
(clinical isolate) & MFC & $1.25^{\mathrm{d}}$ & $1.00^{\mathrm{c}}$ & $0.50^{\mathrm{d}}$ \\
C. tropicalis & MIC & $0.31^{\mathrm{c}}$ & $0.30^{\mathrm{b}}$ & $0.25^{\mathrm{d}}$ \\
(ATCC 750) & MFC & $0.62^{\mathrm{c}}$ & $0.50^{\mathrm{b}}$ & $0.50^{\mathrm{d}}$ \\
\hline
\end{tabular}

In each column different letters means significant difference between MICs and MFCs values for each fungal species tested $(p<0.05)$.

Antifungal activity of $O$. spinosa was the most prominent against food isolated species Penicillium aurantiogriseum with minimum inhibitory concentration (MIC) of $0.02 \mathrm{mg} / \mathrm{mL}$ and minimum fungicidal concentration (MFC) of $0.04 \mathrm{mg} / \mathrm{mL}$. On the other hand, the most resistant species to the effect of O. spinosa methanolic extract was Penicillium ochrochloron, a species frequently isolated from the soil and apples, with MIC of $5.00 \mathrm{mg} / \mathrm{mL}$ and MFC of $10 \mathrm{mg} / \mathrm{mL}$. Antifungal activity of tested extract was the most prominent against Penicillium aurantiogriseum followed by Aspergillus fumigatus, Candida tropicalis, A. versicolor, A. niger, Trichoderma viride, P. funiculosum, C. albicans, C. krusei, A. ochraceus and $P$. ochrochloron. As far as we know, this is the first study reporting antifungal activity of the methanolic extract obtained from the herb of $O$. spinosa.

The activity of $O$. spinosa was comparable to the activity of commercial fungicides. The most promising effect was achieved on A. fumigatus and P. aurantiogriseum, to which commercial antifungal drugs ketoconazole and bifonazole showed weaker activity when compared to the antifungal action of O. spinosa. Most of the tested microfungi strains gave the similar results regarding MICs and MFCs, which were in the activity range of tested commercial positive controls (ketoconazole and bifonazole).

Previous literature data indicated antifungal potential of extract obtained from the roots of $O$. spinosa, which is traditionally used in ethnomedicine [25]. Results obtained in this study indicate that O. spinosa methanolic extract obtained from the aerial plant parts possessed antifungal properties as well. A study by Deliorman Orhan et al., [25] indicated that the infusion made from Ononidis Radix is active against the following fungal species: Candida albicans (MIC $0.016 \mathrm{mg} / \mathrm{mL} ; \mathrm{MFC} 0.064 \mathrm{mg} / \mathrm{mL}$ ), C. tropicalis (MIC $0.016 \mathrm{mg} / \mathrm{mL}$; MFC $0.064 \mathrm{mg} / \mathrm{mL}$ ), C. parapsilopsis (MIC $0.008 \mathrm{mg} / \mathrm{mL}$; MFC $0.016 \mathrm{mg} / \mathrm{mL}$ ), Trichophyton rubrum (MIC $0.016 \mathrm{mg} / \mathrm{mL}$; MFC not active), Epidermophyton floccosum (MIC $0.066 \mathrm{mg} / \mathrm{mL}$; MFC not active) and Microsporum gypseum (MIC $0.032 \mathrm{mg} / \mathrm{mL}$; MFC not active) [25]. Although in the paper by Deliorman Orhan et al., [25] the antifungal action of the O. spinosa root infusion was analyzed, obtained results are comparable to ours. Furthermore, ethanolic and water solutions of the ashes obtained from O. spinosa plant [3] showed anticandidal activity. Fungicidal concentrations were in range of $1.25 \mu \mathrm{g} / \mathrm{mL}$ (towards C. albicans) to $40 \mu \mathrm{g} / \mathrm{mL}$ (towards C. glabrata) for ethanolic ash solution; and from $1.25 \mu \mathrm{g} / \mathrm{mL}$ for C. albicans and to not active against C. glabrata for aqueous ash solution [3].

Currently, some synthetic antifungals are associated with some adverse effects and there is still no effective cure for some fungal infections in humans [26]. Namely, it has been revealed that 
infections caused by anthropophilic and zoophilic fungi, which represent the most common fungal infections limited to human and animal skin, nails and mucous membranes, are frequently difficult to treat with topical therapeutics and in some cases they may require long term treatment with systemic antifungals [27]. Furthermore, fungicides used in agricultural industry to prevent growth of phytopathogenic fungi may have harmful effects on the environment, as well as on humans and animals through further food chain [28]. Results obtained in this study showed that aerial parts of O. spinosa might provide a good basis for development of natural antifungals. Therefore, this study presents one of the many attempts to resolve issues arisen from the use of synthetic antifungal preparations, both in the treatment of humans and animals, as well as in application in agricultural industry.

\subsection{Antibiofilm Activity of O. spinosa}

In this study antibiofilm activity of the O. spinosa methanolic extract was tested on C. albicans, C. krusei and C. tropicalis (Table 3). These species are able to form structured communities that are attached to surfaces by specific signaling molecules [26]. The results of this study pointed to antibiofilm activity of $O$. spinosa (Table 3). As far as we know, these are the first results on antibiofilm activity of O. spinosa extract obtained from the plant aerial parts. Furthermore, MIC and MFC values of O. spinosa extract towards biofilms were higher when compared to MIC and MFC values obtained for free floating cells tested in microdilution assay (Table 2). C. krusei biofilm was more susceptible to the antibiofilm activity of $O$. spinosa. Importantly, the obtained results for O. spinosa extract (MIC $2.5 \mathrm{mg} / \mathrm{mL}$ and MFC $5 \mathrm{mg} / \mathrm{mL}$ ) towards biofilm of C. krusei are comparable to those obtained for commercial antifungal drug fluconazole (MIC $2 \mathrm{mg} / \mathrm{mL}$ and MFC $3 \mathrm{mg} / \mathrm{mL}$ ), indicating the similar range of antibiofilm concentrations. Furthermore, MIC value of $O$. spinosa extract $(5.00 \mathrm{mg} / \mathrm{mL})$ obtained on C. albicans biofilm was lower in comparison to the MIC value of fluconazole $(8 \mathrm{mg} / \mathrm{mL})$. These results indicate very promising antibiofilm action of $O$. spinosa.

Table 3. Activity of $O$. spinosa extract and a reference compound fluconazole against biofilm (plaque) formation of Candida strains (MIC and MFC, $\mathrm{mg} / \mathrm{mL}$ ).

\begin{tabular}{|c|c|c|c|c|}
\hline \multirow{2}{*}{ Fungi } & \multicolumn{2}{|c|}{ O. spinosa Methanolic Extract } & \multicolumn{2}{|c|}{ Fluconazole } \\
\hline & MIC & MFC & MIC & MFC \\
\hline $\begin{array}{c}\text { C. albicans } \\
\text { (ATCC 10231) }\end{array}$ & $5.00^{b}$ & $10.00^{b}$ & $8.00^{c}$ & $9.00^{\mathrm{c}}$ \\
\hline $\begin{array}{c}\text { C. krusei } \\
\text { (clinical isolate) }\end{array}$ & $2.50^{\mathrm{a}}$ & $5.00^{\mathrm{a}}$ & $2.00^{a}$ & $3.00^{\mathrm{a}}$ \\
\hline $\begin{array}{l}\text { C. tropicalis } \\
\text { (ATCC 750) }\end{array}$ & $5.00^{b}$ & $10.00^{b}$ & $3.00^{b}$ & $6.00^{b}$ \\
\hline
\end{tabular}

In each column different letters means significant difference between MICs and MFCs values for each fungal species tested $(p<0.05)$.

\subsection{Insights into the Modes of Antifungal Action}

Ergosterol is one of the crucial molecules found in fungal cell membranes. Since it is a vital molecule for fungal survival, the enzymes involved in its biosynthesis often present targets for the activity of effective antifungals [29]. Herein, we studied the survival of C. albicans in the presence of externally added increasing concentrations of ergosterol $(25-100 \mu \mathrm{g} / \mathrm{mL})$ and serial dilutions of the $O$. spinosa extract in order to determine whether the extract achieves its antifungal effect via disruption of ergosterol biosynthetic pathway. The results presented in the Figure 2 revealed that MFC values were increased with increasing concentrations of external ergosterol. This is leading to the conclusion that ergosterol biosynthetic pathway is disrupted by compounds presented in O. spinosa extract. 


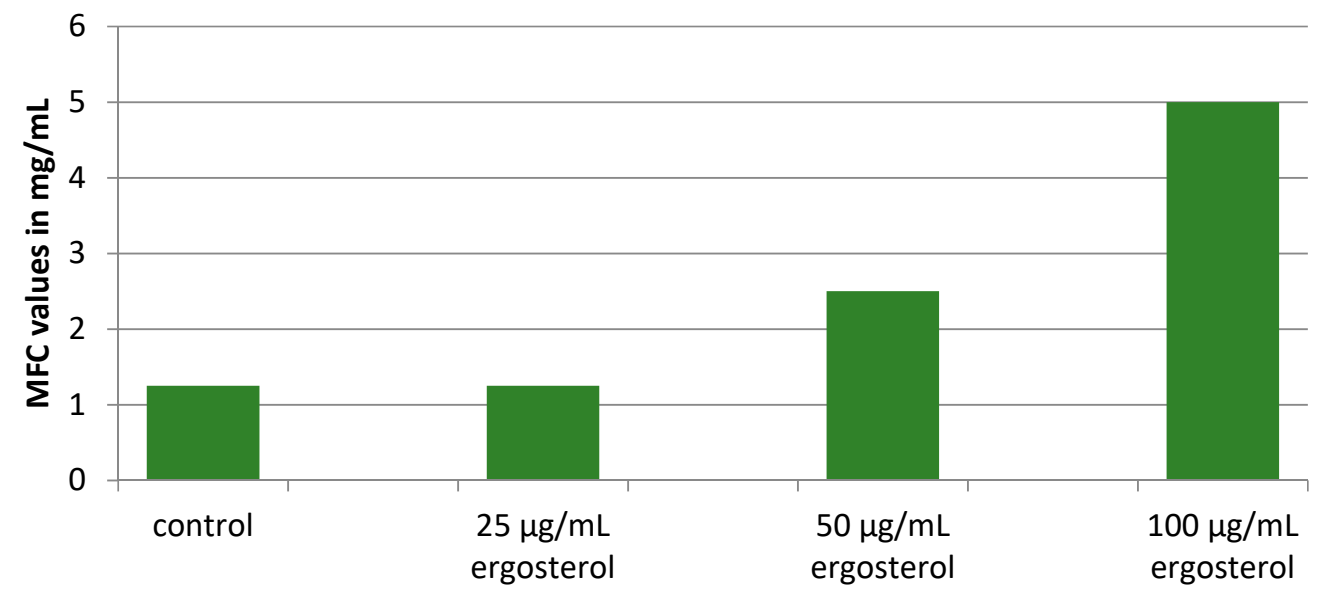

Figure 2. Minimum fungicidal concentrations (MFC) of $O$. spinosa methanolic extract against $C$. albicans in the presence of different ergosterol concentrations. There was no statistically significant difference between control sample and sample with added $25 \mu \mathrm{g} / \mathrm{mL}$ of ergosterol, while there was spastically significant difference between control ${ }^{\mathrm{a}}, 25^{\mathrm{a}} \mu \mathrm{g} / \mathrm{mL}$ and $50^{\mathrm{b}} \mu \mathrm{g} / \mathrm{mL}$ and $100^{\mathrm{c}} \mu \mathrm{g} / \mathrm{mL}$ of added ergosterol $(p<0.05),{ }^{a}, \mathrm{~b}, \mathrm{c}$ statistically significant difference between samples.

The effect of O. spinosa extract on C. albicans was further analyzed at the level of cell membrane permeability. A membrane permeability assay was performed in order to evaluate if breakdown of cytoplasmic membrane occurs in the presence of $2 \times$ MIC concentration of the extract. Obtained results revealed time-dependent effect of $O$. spinosa extract on the cell membrane permeability (Figure 3 ). Namely, optical densities at $260 \mathrm{~nm}$ and $280 \mathrm{~nm}$ were increased rapidly after $30 \mathrm{~min}$ of incubation and achieved maximum values after $90 \mathrm{~min}$, indicating release of intracellular components from the cells of C. albicans to the extracellular compartment. The results pointed out that the fungal cell membrane represents one of the targets of $O$. spinosa antifungal action.

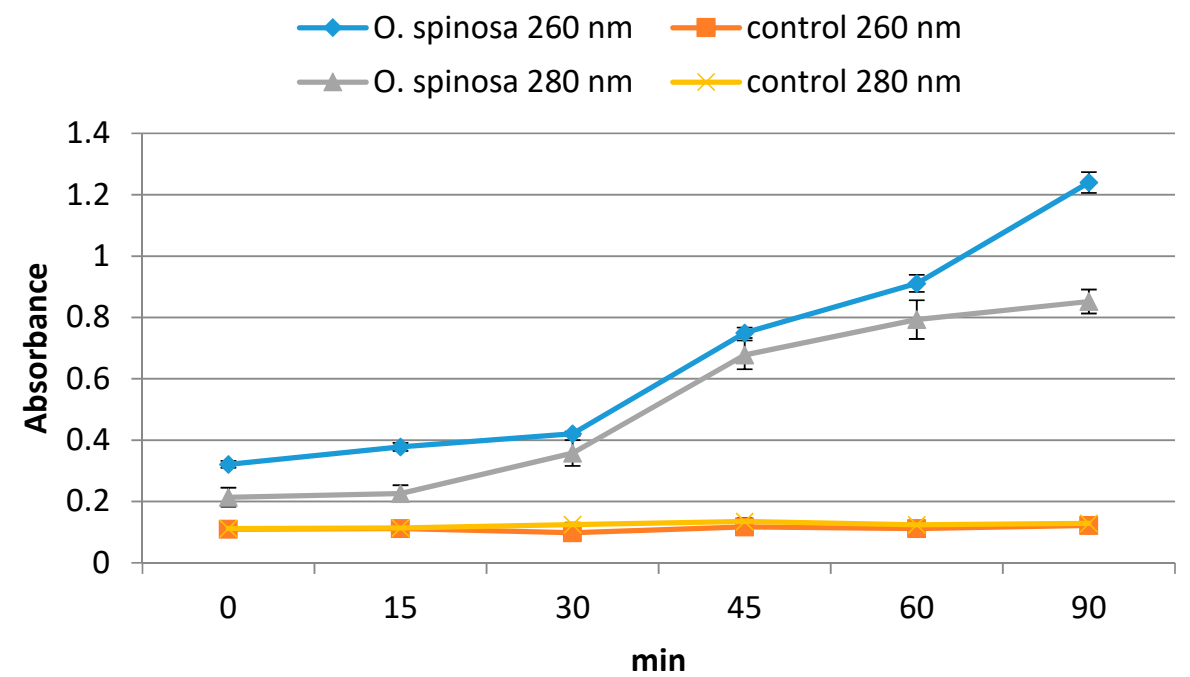

Figure 3. Leakage of cellular components recorded by absorbance at 260 and $280 \mathrm{~nm}$ in C. albicans treated with $O$. spinosa methanolic extract at $2 \times$ MIC (minimum inhibitory concentration). There has been significant difference between control and treated samples $(p<0.05)$.

In general, results obtained in this study presented preliminary insight into the mode of antifungal action of $O$. spinosa extract. Based on the results it could be concluded that the extract exerted its antifungal activity by disruption of ergosterol biosynthesis and by modulation of cell membrane permeability. This study represents one of the first reports exploring possible modes of action of $O$. spinosa methanolic extract obtained from the aerial parts of the plant. 
Fungal pathogens have the eukaryotic conserved signaling pathways, which enable them to adapt and survive in the environment, including host cells [29]. The slight differences of fungal eukaryotic structure in relation to human cells are attractive for antifungal drug development [30]. The most important targets of antifungal drugs currently used are enzymes involved in ergosterol biosynthetic pathway [29]. Based on the literature data it might be concluded that targeting ergosterol biosynthetic pathway is the most common mode of action of major antifungals. Having in mind that ergosterol pathway is already successfully been targeted by antifungal substances currently in use [29], natural products that are found to act against targets within ergosterol biosynthetic pathway are more likely to be effective. Besides targeting ergosterol biosynthetic pathway, some antifungal products are proved to have the power to penetrate and disrupt the fungal cell membranes, rich in unsaturated fatty acids, which leads to rearrangement of membrane constituents, loss of cell viability and, eventually, cell dead [31]. Here we showed that extract of O. spinosa provoked leakage of intracellular contents from $C$. albicans cells, which is one of the indicators pointing to cell membrane as additional target of the tested extract. Our results further showed that the extract of $O$. spinosa is complex mixture of the compounds that acted by different mechanisms. It is interesting to point that the chance of developing fungal resistance to the extract is very unlikely since the extract is acting by different mechanisms affecting different targets. It makes $O$. spinosa extract a strong candidate for future application.

\subsection{Evaluation of Cytotoxicity of the O. spinosa Methanolic Extract on Primary Human Gingival Fibroblast Cells}

Currently, a wide range of different immortalized and primary cells and tissue models are available for in vitro toxicity evaluation. The evaluation of drug cytotoxicity is an important step in biomedical research and represents a primary consideration covering drug selection. Additionally, the first step in the development of novel antifungal drugs includes toxicity studies on human cells in culture. We used human gingival fibroblast (HGF-1) cells to test possible cytotoxic effect of the extract on primary human cells.

No cytotoxicity of the $O$. spinosa methanolic extract on the HGF-1 cells was observed with concentration up to $400 \mu \mathrm{g} / \mathrm{mL}$; a concentrations which is considered as the limit of toxicity (Figure $4 \mathrm{~A}$ ). Namely, as shown in the Figure $4 \mathrm{~A}$, there was no statistical difference $(p<0.05)$ in relative growth rate between HGF-1 cells treated with different concentrations of the O. spinosa extract and non-treated control cells. Additionally, we analyzed morphology of the control HGF-1 cells and HGF-1 cells treated with $400 \mu \mathrm{g} / \mathrm{mL}$ of $O$. spinosa extract (Figure $4 \mathrm{~B}, \mathrm{C}$ ). Obtained results revealed that the treatment of the cells with the extract did not induce changes of the cell morphology (Figure 4C) when compared to the morphology of non-treated fibroblast cells (Figure 4B). Therefore, we showed that $O$. spinosa had no influence on primary human gingival fibroblast cells, regarding the growth rate and cellular morphology. 
A
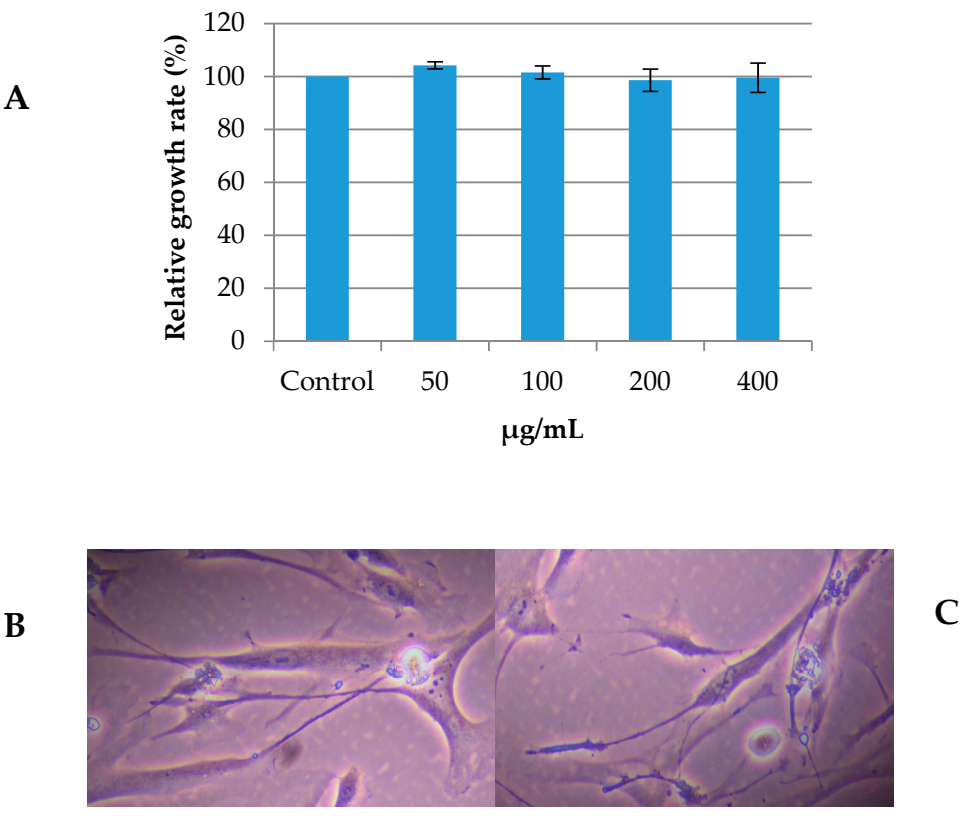

Figure 4. (A) Relative growth rate (\%) of human gingival fibroblast (HGF-1) cells treated with different concentrations of $O$. spinosa extract showing no statistical difference between treatments $(p<0.05)$; (B) representative phase contrast image of non-treated control cells and (C) representative phase contrast image of cells treated with O. spinosa extract $(400 \mu \mathrm{g} / \mathrm{mL})$.

\section{Materials and Methods}

\subsection{Standards and Reagents}

Acetonitrile (99.9\%) was of high-performance liquid chromatography (HPLC) grade from Fisher Scientific (Lisbon, Portugal). Phenolic compound standards (caffeic acid, ferulic acid, hesperetin, naringenin, quercetin-3-O-glucoside and quercetin-3-O-rutinoside) were from Extrasynthèse (Genay, France). Formic acid was purchased from Sigma-Aldrich (St. Louis, MO, USA). All other general laboratory reagents were from Panreac Química S.L.U. (Barcelona, Spain). Water was treated in a Milli-Q water purification system (TGI Pure Water Systems, Greenville, SC, USA).

\subsection{Collection and Extraction of O. spinosa}

The aerial parts of wild growing O. spinosa were collected in Vranje (Serbia) in July 2018 and authenticated. The samples were dried, prepared and successively extracted with methanol as previously described by Ćirić et al., [32].

\subsection{Analysis of Phenolic Compounds}

The phenolic profile was determined by LC-DAD-ESI/MSn (Dionex Ultimate 3000 UPLC, Thermo Scientific, San Jose, CA, USA), and separated and identified as previously described by Bessada et al., [33]. The obtained extracts were redissolved at a concentration of $20 \mathrm{mg} / \mathrm{mL}$ with the ethanol:water (80:20, $v / v)$ mixture. A double online detection was performed using a DAD (280, 330 and $370 \mathrm{~nm}$ as preferred wavelengths) and a mass spectrometer (MS). The MS detection was performed in a negative mode, using a Linear Ion Trap LTQ XL mass spectrometer (Thermo Finnigan, San Jose, CA, USA) equipped with an ESI source.

The identification was performed based on their chromatographic behavior and UV-vis and mass spectra by comparison with standard compounds, when available, and data reported in the literature giving a tentative identification. Data acquisition was carried out with Xcalibur ${ }^{\circledR}$ data system (Thermo Finnigan, San Jose, CA, USA). In order to perform a quantitative analysis, a calibration curve for each 
available phenolic standard was constructed based on the UV-vis signal. The quantification of the identified phenolic compounds, for which a commercial standard was not available, was performed through the calibration curve of the most similar available standard: caffeic acid ( $y=388345 x+406369$, $\left.R^{2}=0.9939\right)$, ferulic acid $\left(y=633126 x-185462, R^{2}=0.999\right)$, hesperetin $\left(y=34156 x+268027, R^{2}=0.9999\right)$, naringenin $\left(y=18433 x+78903, R^{2}=0.9998\right)$, quercetin-3-O-glucoside $\left(y=34843 x-160173, R^{2}=0.9998\right)$, and quercetin-3-O-rutinoside $\left(y=13343 x+76751, R^{2}=0.9998\right)$. The results were expressed as $\mathrm{mg} / \mathrm{g}$ of extract.

\subsection{Antifungal Activity Assay}

The antifungal activity of $O$. spinosa methanolic extract was tested against the following fungi: Aspergillus fumigatus (ATCC 1022), A. niger (ATCC 6275), A. versicolor (ATCC 11730), A. ochraceus (ATCC 12066), P. funiculosum (ATCC 8725), P. ochrochloron (ATCC 9112), P. aurantiogriseum (food isolate), Trichoderma viride (IAM 5061), Candida albicans (ATCC 10231), C. tropicalis (ATCC 750) and C. krusei (clinical isolate). All microorganisms used in this study were deposited at the Mycological Laboratory, Institute for Biological Research "Siniša Stanković" - National institute of Republic of Serbia, University of Belgrade, Serbia.

A modified microdilution technique was utilized to investigate the antifungal activity as described previously by Soković et al., and Clinical and Laboratory Standards Institute [34,35]. Briefly, MICs and MFCs were determined by a serial dilution technique using 96-well microtiter plates. The extract of O. spinosa was dissolved in 5\% dimethyl-sulfoxide-DMSO. The commercial fungicides bifonazole and ketokonazole (Srbolek, Belgrade, Serbia) were used as positive controls (1-3500 $\mu \mathrm{g} / \mathrm{mL}$ of DMSO), while $5 \%$ dimethyl-sulfoxide in water was used as a negative control.

\subsection{Biofilm Inhibition Assay on Candida Strains}

The effect of $O$. spinosa methanolic extract on biofilm formation of C. albicans, C. krusei and C. tropicalis was determined as previously described by Popovic et al. [36]. The extract of O. spinosa was dissolved in 5\% dimethyl-sulfoxide-DMSO. Staining process with crystal violet was used for determination of biofilm reduction and further measuring the UV absorbance of stain at $570 \mathrm{~nm}$ using a plate reader. MIC was defined as the minimum concentration of antifungal agent that inhibited further growth of the initial biofilm, and minimum fungicidal concentration (MFC) was defined as the concentration presenting no fungal growth (empty well). Fluconazole (dissolved in 5\% DMSO) was used as a positive control, while $5 \%$ DMSO in water was used as a negative control.

\subsection{Insights into the mode of Antifungal Action: Ergosterol Binding and Membrane Permeability Assays}

Assays were performed on the Candida albicans strain. Serial dilutions of the extracts were done in microtiter plates as for microdilution method with addition of ergosterol (25-100 $\mu \mathrm{g} / \mathrm{mL})$ [3]. After $24 \mathrm{~h}$ of incubation at $37^{\circ} \mathrm{C}$, MFCs were determined as explained for antifungal activity assay.

The effect of the $O$. spinosa extract on membrane permeability was evaluated as previously described by Stojković et al. [37]. Strain was incubated with the O. spinosa extract at the $2 \times$ MIC for different time periods: 15, 30, 45, 60 and $90 \mathrm{~min}$. C. albicans incubated with $10 \mathrm{mM} \mathrm{PBS}(\mathrm{pH}$ 7.4) was used as a control. The optical density was measured at $260 \mathrm{~nm}$ and $280 \mathrm{~nm}$ (Aglient 8453 spectrophotometer) at room temperature $\left(25^{\circ} \mathrm{C}\right)$.

\subsection{Investigation of O. spinosa Methanolic Extract Cytotoxic Activity}

Cytotoxic effect of $O$. spinosa methanolic extract was determined on human gingival fibroblasts cells HGF-1 (ATCC ${ }^{\circledR}$ CRL-2014 ${ }^{\mathrm{TM}}$ ) using crystal violet assay as described by Feoktistova et al., [38], with some modifications. The extract of $O$. spinosa was dissolved in PBS to a final concentration of $8 \mathrm{mg} / \mathrm{mL}$. HGF- 1 cells were grown in fibroblast basal medium (ATCC ${ }^{\circledR}$ PCS-201-030 ${ }^{\mathrm{TM}}$ ) at $37^{\circ} \mathrm{C}$ in a $\mathrm{CO}_{2}$ incubator. Forty-eight hours before treatment, HGF-1 cells were seeded in a 96-well microtiter adhesive plate at a seeding density of $4 \times 10^{3}$ cells per well. After $48 \mathrm{~h}$, the medium was removed 
and the cells were treated for the next $48 \mathrm{~h}$ with various concentrations of the extract in triplicate wells. Subsequently, the medium was removed; the cells were washed twice with PBS and stained with $0.4 \%$ crystal violet staining solution for $20 \mathrm{~min}$ at room temperature. Afterwards, crystal violet staining solution was removed; the cells were washed in a stream of tap water and left to air dry at room temperature. The absorbance of dye dissolved in methanol was measured in a plate reader at $570 \mathrm{~nm}$. The results were expressed as relative growth rate (\%).

\subsection{Statistical Analysis}

All analyses were performed in triplicate; each replicate was quantified also three times. Data were expressed as mean standard deviation, where applicable. In the cases where statistical significance differences were identified, the dependent variables were compared using Tukey's honestly significant difference (HSD) test.

\section{Conclusions}

The present study revealed underestimated biological potential of the aerial parts of $O$. spinosa plant. Methanolic extract was a good source of phenolic compounds indicated by the presence of phenolic acids, flavonoids and isoflavonoids. Flavonoids were the most dominant class of the identified compounds, followed by phenolic acids and isoflavonoids. For the first time, we reported the presence of phenolic acids in the methanolic extract of $O$. spinosa, together with the types of identified flavonoids, which were not previously reported in the investigated species. This is the first study reporting antifungal and antibiofilm activities of the methanolic extract obtained from the herb of $O$. spinosa. Based on the results it could be concluded that the extract exerted its antifungal activity by disruption of ergosterol biosynthesis and by modulation of cell membrane permeability. Finally, extract was not toxic to HGF-1 cells, which makes it the good candidate for further antifungal drug development.

Author Contributions: D.S. conceived and designed the research, was enrolled in all the analyses and prepared the draft version of the manuscript; L.B. performed chemical analyses, data curation and methodology, reviewed and edited the final manuscript; D.D. was engaged in the experiments on in vitro cytotoxicity, interpreted results and edited the draft version of the manuscript; M.I.D. performed the analyses regarding chemical composition and interpreted and discussed the obtained results; M.S. supervised the experiments on cell line, edited the final draft of the manuscript; I.C.F.R.F. obtained funding, supervised the project, reviewed and edited the final manuscript; M.D.S. supervised the whole project, and edited the final manuscript. All authors have read and agreed to the published version of the manuscript.

Funding: This work has been supported by Ministry of Education, Science and Technological Development of Republic of Serbia (451-03-68/2020-14/200007 and 451-03-68/2020-14/200042). The authors are grateful to the Foundation for Science and Technology (FCT, Portugal) and FEDER under Program PT2020 for financial support to CIMO (UIDB/00690/2020); national funding by FCT, P.I., through the institutional scientific employment program-contract for M.I. Dias and L. Barros; to FEDER-Interreg España-Portugal program for financial support through the project 0377_Iberphenol_6_E and TRANSCoLAB 0612_TRANS_CO_LAB_2_P.

Conflicts of Interest: The authors declare no conflict of interest.

\section{References}

1. Bongomin, F.; Gago, S.; Oladele, R.O.; Denning, D.W. Global and Multi-National Prevalence of Fungal Diseases-Estimate Precision. J. Fungi 2017, 3, 57. [CrossRef]

2. Donlan, M.R.; Costerton, W.J. Biofilms: Survival mechanisms of clinically relevant microorganisms. Clin. Microbiol. Rev. 2002, 15, 167-193. [CrossRef] [PubMed]

3. Altuner, E.M.; Çeter, T.; Lşlek, C. Investigation of antifungal activity of Ononis spinosa L. ASH used for the therapy of skin infections as folk remedies. Mikrobiyoloji Bul. 2010, 44, 633-639.

4. Diklić, N. Rod Ononis L. In Flora SR Srbije, 1st ed.; Josifović, M., Ed.; Srpska Akademija nauke i umetnosti: Beograd, Srbija, 1992; Volume 4, pp. 392-396.

5. Gampe, N.; Darcsi, A.; Kursinszki, L.; Béni, S. Separation and characterization of homopipecolic acid isoflavonoid ester derivatives isolated from Ononis spinosa L. root. J. Chromatogr. B 2018, 1091, 21-28. [CrossRef] [PubMed] 
6. Leporatti, M.L.; Ivancheva, S. Preliminary comparative analysis of medicinal plants used in the traditional medicine of Bulgaria and Italy. J. Ethnopharmacol. 2003, 87, 123-142. [CrossRef]

7. Mamedov, N.; Gardner, Z.; Craker, L.E. Medicinal plants used in Russia and Central Asia for the treatment of selected skin conditions. J. Herbs Spices Med. Plants 2005, 11, 191-222. [CrossRef]

8. Altanlar, N.; Saltan Çitoğlu, G.; Sever Yılmaz, B. Antilisterial activity of some plants used in folk medicine. Pharm. Biol. 2006, 44, 91-94. [CrossRef]

9. Çakilcioğlu, U.; Türkoğlu, I. An ethnobotanical survey of medicinal plants in Sivrice (Elazı̆̆-Turkey). J. Ethnopharmacol. 2010, 132, 165-175. [CrossRef]

10. Benedec, D.; Vlase, L.; Oniga, I.; Toiu, A.; Tamas, M.; Tiperciuc, B. Isoflavonoids from Glycyrrhiza sp. and Ononis spinosa. Farmacia 2012, 60, 615-620.

11. Daruhazi, A.E.; Szarka, S.; Hethelyi, E.; Simandi, B.; Gyurjan, I.; Laszlo, M.; Szoke, E. GC-MS identification and GC-FID quantitation of terpenoids in Ononidis spinosae Radix. Chromatographia 2008, 68, 71-76. [CrossRef]

12. Jimenez-Gonzales, L.; Alvarez-Corral, M.; Munoz-Dorado, M.; Rodriguez-Garcia, I. Pterocarpans: Interesting natural products with antifungal activity and other biological properties. Phytochem. Rev. 2008, 7, 125-154. [CrossRef]

13. Jaradat, N.A.; Al-Masri, M.; Zaid, A.N.; Hussein, F.; Al-Rimawi, F.; Mokh, A.A.; Mokh, J.A.; Ghonaim, S. Phytochemical, antimicrobial and antioxidant preliminary screening of a traditional Palestinian medicinal plant, Ononis pubescens L. Eur. J. Integr. Med. 2017, 14, 46-51. [CrossRef]

14. Dénes, T.; Bartha, S.G.; Kerényi, M.; Varga, E.; Balázs, V.L.; Csepregi, R.; Papp, N. Histological and antimicrobial study of Ononis arvensis L. Acta Biol. Hung. 2017, 68, 321-333. [CrossRef] [PubMed]

15. Tunde, D.; Papp, N.; Marton, K.; Kaszas, A.; Felinger, A.; Varga, E.; Boros, B. Polyphenol Content of Ononis arvensis L. and Rhinanthus serotinus (Schönh. ex Halácsy \& Heinr. Braun) Oborny Used in the Transylvanian Ethnomedicine. Int. J. Pharmacogn. Phytochem. 2015, 30, 2051-2058.

16. Mezrag, A.; Malafronte, N.; Bouheroum, M.; Travaglino, C.; Russo, D.; Milella, L.; Severino, L.; De Tommasi, N.; Braca, A.; Dal Piaz, F. Phytochemical and antioxidant activity studies on Ononis angustissima L. aerial parts: Isolation of two new flavonoids. Nat. Prod. Res. 2017, 31, 507-514. [CrossRef]

17. Barros, L.; Dueñas, M.; Pinela, J.; Carvalho, A.M.; Buelga, C.S.; Ferreira, I.C.F.R. Characterization and Quantification of Phenolic Compounds in Four Tomato (Lycopersicon esculentum L.) Farmers' Varieties in Northeastern Portugal Homegardens. Plant Food Hum. Nutr. 2012, 67, 229-234. [CrossRef]

18. Chen, H.; Zhang, Q.; Wang, X.; Yang, J.; Wang, Q. Qualitative analysis and simultaneous quantification of phenolic compounds in the aerial parts of Salvia miltiorrhiza by HPLC-DAD and ESI/MSn. Phytochem. Anal. 2011, 22, 247-257. [CrossRef]

19. Addotey, J.N.; Lengers, I.; Jose, J.; Gampe, N.; Béni, S.; Petereit, F.; Hensel, A. Isoflavonoids with inhibiting effects on human hyaluronidase-1 and norneolignan clitorienolactone B from Ononis spinosa L. root extract. Fitoterapia 2018, 130, 169-174. [CrossRef]

20. Öz, B.E.; İşcan, G.S.; Akkol, E.K.; Süntar, İ.; Acıkara, Ö.B. Isoflavonoids as wound healing agents from Ononidis Radix. J. Ethnopharmacol. 2018, 211, 384-393.

21. Gampe, N.; Darcsi, A.; Lohner, S.; Béni, S.; Kursinszki, L. Characterization and identification of isoflavonoid glycosides in the root of Spiny restharrow (Ononis spinosa L.) by HPLC-QTOF-MS, HPLC-MS/MS and NMR. J. Pharm. Biomed. 2016, 123, 74-81. [CrossRef]

22. Pietta, P.; Calatroni, A.; Zio, C. High-performance liquid chromatographic analysis of flavonoids from Ononis spinosa L. J. Chromatogr. A 1983, 280, 172-175. [CrossRef]

23. McCue, P.; Shetty, K. Health benefits of soy isoflavonoids and strategies for enhancement: A review. Crit. Rev. Food Sci. 2004, 44, 361-367. [CrossRef] [PubMed]

24. Zaheer, K.; Humayoun Akhtar, M. An updated review of dietary isoflavones: Nutrition, processing, bioavailability and impacts on human health. Crit. Rev. Food Sci. 2017, 57, 1280-1293. [CrossRef] [PubMed]

25. Deliorman Orhan, D.; Özçelik, B.; Hoşbaş, S.; Vural, M. Assessment of antioxidant, antibacterial, antimycobacterial, and antifungal activities of some plants used as folk remedies in Turkey against dermatophytes and yeast-like fungi. Turk. J. Biol. 2012, 36, 672-686.

26. Smiljković, M.; Kostić, M.; Stojković, D.; Glamočlija, J.; Soković, M. Could flavonoids compete with synthetic azoles in diminishing Candida albicans infections? A comparative review based on in vitro studies. Curr. Med. Chem. 2019, 26, 2536-2554. [CrossRef] 
27. Ernst, E.; Pittler, M.H.; Stevinson, C.; White, A. The Desktop Guide to Complementary and Alternative Medicine; Mosby: Edinburgh, UK, 2001.

28. Aleksić, M.; Stanisavljević, D.; Smiljković, M.; Vasiljević, P.; Stevanović, M.; Soković, M.; Stojković, D. Pyrimethanil: Between efficient fungicide against Aspergillus rot on cherry tomato and cytotoxic agent on human cell lines. Ann. Appl. Biol. 2019, 175, 228-235. [CrossRef]

29. Nicola, A.M.; Albuquerque, P.; Paes, H.C.; Fernandes, L.; Costa, F.F.; Kioshima, E.S.; Abadio, A.K.R.; Bocca, A.L.; Felipe, M.S. Antifungal drugs: New insights in research \& development. Pharmacol. Therapeut. 2019, 195, 21-38.

30. Chauhan, N.; Calderone, R. Two-Component Signal Transduction Proteins as Potential Drug Targets in Medically Important Fungi. Infect. Immun. 2008, 76, 4795-4803. [CrossRef]

31. Tariq, S.; Wani, S.; Rasool, W.; Shafi, K.; Bhat, M.A.; Prabhakar, A.; Shalla, A.H.; Rather, M.A. A comprehensive review of the antibacterial, antifungal and antiviral potential of essential oils and their chemical constituents against drug-resistant microbial pathogens. Microb. Pathog. 2019, 134, 103580. [CrossRef]

32. Ćirić, A.; Kruljević, I.; Stojković, D.; Fernandes, Â.; Barros, L.; Calhelha, R.C.; Ferreira, I.C.F.R.; Soković, M.; Glamočlija, J. Comparative investigation on edible mushrooms Macrolepiota mastoidea, M. rhacodes and $M$. procera: Functional foods with diverse biological activities. Food Funct. 2019, 10, 7678-7686. [CrossRef] [PubMed]

33. Bessada, S.M.F.; Barreira, J.C.M.; Barros, L.; Ferreira, I.C.F.R.; Oliveira, M.B.P.P. Phenolic profile and antioxidant activity of Coleostephus myconis (L.) Rchb.f.: An underexploited and highly disseminated species. Ind. Crop Prod. 2016, 89, 45-51. [CrossRef]

34. Soković, M.; Van Griensven, L.J.L.D. Antimicrobial activity of essential oils and their components against the three major pathogens of the cultivated button mushroom, Agaricus bisporus. Eur. J. Plant Pathol. 2006, 116, 211-224. [CrossRef]

35. CLSI. Clinical and Laboratory Standards Institute Methods for Dilution Antimicrobial Susceptibility Tests for Bacteria that Grow Aerobically, 8th ed.; CLSI Publication M07-A8; Clinical and Laboratory Standards Institute: Wayne, PA, USA, 2009.

36. Popović, V.; Stojković, D.; Nikolić, M.; Heyerick, A.; Petrović, S.; Soković, M.; Niketić, M. Extracts of three Laserpitium L. species and their principal components laserpitine and sesquiterpene lactones inhibit microbial growth and biofilm formation by oral Candida isolates. Food Funct. 2015, 6, 1205-1211. [CrossRef]

37. Stojković, D.S.; Živković, J.; Soković, M.; Glamočlija, J.; Ferreira, I.C.F.R.; Janković, T.; Maksimović, Z. Antibacterial activity of Veronica montana L. extract and of protocatechuic acid incorporated in a food system. Food Chem. Toxicol. 2013, 55, 209-213. [CrossRef] [PubMed]

38. Feoktistova, M.; Geserick, P.; Leverkus, M. Crystal Violet Assay for Determining Viability of Cultured Cells. Cold Spring Harb. Protoc. 2016, 4, 087379. [CrossRef] [PubMed] 